\title{
Microirrigation for Citrus Production in Florida
}

\author{
Allen G. Smajstrla \\ Agricultural Engineering Department, University of Florida, Gainesville, FL 32611
}

Citrus is believed to have been introduced to Florida by the explorer Ponce de Leon in 1513. Commercial production for export began in the late 1700 s and citrus has been a major agricultural crop since the late 1800s (Hardy, 1989). Today, $\approx 72 \%$ of the citrus produced in the United States is grown in Florida (Freie and Young, 1989).

The growth of the Florida citrus industry has been punctuated by periodic downturns due to freeze damage. For example, the Great Freeze of 1894-95 almost totally wiped out the industry (Hardy, 1989). Land area in citrus production peaked at 340,000 ha in the early 1970 s and then declined to $\approx 204,000$ ha in the mid-1980s because of severe freezes in 1983 and 1985 (Freie and Young, 1989). Production area increased to 294,000 ha in 1990 (Bush, 1990c) despite a severe freeze in 1989.

The Florida citrus belt is located in a subtropical climate zone that receives 1300 to $1500 \mathrm{~mm}$ of rainfall annually. However, sandy, lowwater-holding capacity soils require irrigation for optimum production (Koo et al., 1973; Reese and Koo, 1976). Citrus is produced on the deep sandy soils typical of Florida's central ridge and on the poorly drained, high-water-table flatwoods soils typical of coastal and southern Florida.

During the 1980s, the Florida citrus industry has been characterized by a gradual migration southward as five severe freezes destroyed $>80,000$ ha of groves in the northern part of the state (Bush, 1990b). Recent growth in the industry has primarily occurred on flatwoods soils that had historically been used as rangelands because they need extensive drainage (Bush, 1990a). These areas also require extensive land forming, including ditch and water-retention basin construction, precision land leveling, and bedding before planting trees.

\section{IRRIGATION ALTERNATIVES}

Florida citrus is irrigated using sprinkler, surface, subirrigation (seepage), and microirrigation systems. Typical highly permeable sandy soils restrict the use of surface irrigation to flood systems that irrigate by building a water table on impermeable subsurface soil layers or on existing high water tables.

Sprinkler systems historically have been used to irrigate the deep sandy soils of Florida's central ridge. Early sprinkler systems used perforated aluminum pipe. Later, permanent solid-set sprinklers, portable guns, and traveling guns became popular, while perforated pipe systems became obsolete, largely because of their high labor requirements.

Citrus can only be grown with artificial drainage on poorly drained flatwoods soils. Field ditches or a combination of field ditches and soil bedding are used to obtain the required surface and subsurface drainage. Historically, sprinkler, seepage, and flood irrigation have been used for citrus production on flatwoods.

Field ditches provide both irrigation and drainage when seepage and flood irrigation systems are used. Ditches are required to maintain or change water table levels in the crop root zone. For seepage irrigation, water tables are maintained at or just below the tree root zone to permit water to move into the root zone by capillary action. For flood irrigation, bedded citrus groves are irrigated by filling field ditches to near the tops of the beds. This high water level is maintained for up to 3 days so that water can infiltrate the beds. Ditches are then drained by pumping excess water into adjacent groves.

The history of microirrigation in Florida citrus is brief. A few growers and researchers experimented with microsystems in the early 1970s, but field management techniques were not developed and the system's benefits were not well documented until the late 1970s and early 1980s. The Irrigation Journal (Trulio, 1960-89) reported an exponential increase in Florida's microirrigated crop area from 2400 ha in 1974 to 15,400 ha in $1980,119,200$ ha in 1985 , and 160,000 ha in 1989, the great majority of which is in citrus production. The $1980 \mathrm{~s}$ has clearly been the decade of acceptance and general use of this technology in Florida.
Drip and microsprinkler systems are used in Florida citrus. Microsprinkler systems are more popular because they 1) require only one emitter per tree; 2) can provide freeze protection, especially for young trees; and 3) increase yield by irrigating a large fraction of the tree root zone.

\section{CURRENT TREND}

Microirrigation has displaced many gun sprinkler systems in existing citrus groves, because the guns have large labor requirements and high pumping costs. Also, gun systems are capable only of infrequent irrigation, and frequent microirrigation increases yield. Microirrigation has likewise displaced many seepage and some flood irrigation systems in existing groves because of demonstrated yield increases.

Microirrigation has displaced relatively few permanent sprinkler irrigation systems, primarily because yield increases with microirrigation have not exceeded those of permanent sprinkler systems, and permanent systems can be used often and with low labor inputs. Also, the lower pumping costs of microsystems are at least partially negated by higher labor and maintenance requirements as compared with sprinkler systems. However, microsystems have displaced sprinklers in areas where high-salinity irrigation water has caused tree damage.

Microirrigation is used on almost all new citrus developments in Florida because of 1) clogging control, 2) production benefits, 3) system costs, 4) water conservation, and 5) favorable governmental regulations.

\section{CONTROL OF CLOGGING}

Many early attempts to use microsystems for citrus irrigation failed because of emitter clogging. These problems have been addressed by improved emitter design and system management, including filtration, flushing, and chemical water treatment.

Many early microirrigation systems used laminar flow emitters or emitters with very small orifices that clogged easily. Current designs emphasize turbulent flow conditions, which help to avoid clogging problems. Other emitters have self-flushing characteristics.

Materials problems were common with early emitter designs. Some early plastics were not compatible with chemical amendments such as chlorine, acids, and fertilizers. Most manufacturers now use materials that have been tested for chemical compatibility-information that is generally available from manufacturers.

The combination of water quality problems and microirrigation emitters with small orifices makes filtration, system flushing, and chemical water treatment necessary in Florida. Screen filtration is required for groundwater sources, while both media (sand) and screen filtration is needed for surface water sources. Sand separators also may be required on some wells. Irrigation systems must permit periodic flushing of both main and lateral pipes.

The chemical quality of irrigation water may lead to clogging from bacterial growth or chemical precipitation. Ford $(1977,1979)$ found that $\mathrm{Fe}$ - and $\mathrm{S}$-mediated bacterial growth were treatable by chlorinating the water. Precipitate problems associated with the high $\mathrm{pH}$ of the Floridan aquifer's groundwater may require injecting acids, sequestering agents, or surfactants (Pitts et al., 1990).

\section{MICROIRRIGATION PRODUCTION BENEFITS}

Microirrigation offers several production benefits-freeze protection, improved young tree growth, yield increases, and chemigationto Florida citrus growers.

\section{Freeze protection}

Many research studies, extension demonstrations, and grower 
experiences have demonstrated that microsprinkler irrigation can provide some freeze protection for citrus in Florida (Buchanan et al., 1982; Davies et al., 1984; Jackson et al., 1986; Oswalt and Parsons, 1981; Parsons et al., 1981, 1982, 1985, 1986; Parsons and Wheaton, 1987). Irrigation is now the preferred freeze protection method in Florida. More than $80 \%$ of the freeze-protected citrus groves use irrigation (Parsons et al., 1989).

Operating microsprinklers continuously under mature tree canopies during freezing conditions provides some protection (Parsons et al., 1982). This practice raises the temperature under trees due to the ambient water temperature and the release of heat of fusion as the water freezes. Climatic factors, especially temperature and wind speed, and grove factors, such as general grove health, tree variety, and acclimation due to previous exposure to low temperatures, affect the degree of protection.

Many studies have demonstrated dramatic results using microsprinkler irrigation for young tree freeze protection. Water is sprayed directly onto trees, covering as much of the tree as possible, especially the bud union and trunk. Often, tree wraps (insulating materials) are also used to cover the tree trunk and bud union (Davies et al., 1984; Jackson et al., 1986). The freezing water maintains the trunk and bud union near $0 \mathrm{C}$ and protects that portion of the tree from subfreezing temperatures-even those well below freezing. Although leaves, fruit, and upper branches may be damaged, this practice protects the main branches (and the associated root system) and allows young trees to recover rapidly following freezes.

Some freeze protection is obtainable with irrigation systems other than microirrigation. Sprinkler systems are often operated to increase the soil water content in anticipation of freezes. This practice increases soil heat conduction to the surface as compared with dry soils; however, it is normally not as effective as continuously applying water during a freeze. Also, over-tree sprinklers cannot be used for freeze protection because ice loads can break mature trees and because they normally operate in zones. Under-tree sprinklers can provide freeze protection; however, cost normally prohibits them from being used to irrigate the entire grove at once.

Citrus growers also flood groves for freeze protection. This practice is only applicable to bedded groves on normally high-water-table soils with adequate available water and, thus, is not available to many citrus areas because of limited water supplies and soil characteristics. Heat released from water-filled ditches or transported from wet soil can help prevent freeze damage. The effectiveness of this practice depends heavily on freeze type and severity.

Before the sharp increases in oil prices in 1973, many growers used oil heaters for freeze protection. Current high oil prices generally restrict this practice to high-value citrus nurseries and other small high-value production systems.

Because of potential freeze protection benefits, many growers install microsprinkler irrigation systems specifically designed for freeze protection. This design costs more than conventional zoned designs because it requires irrigating the entire production area simultaneously and continuously during freezes.

\section{Improved young tree growth}

Microirrigation increases young tree growth compared with conventional irrigation methods. A net return on investment is often realized 1 to 2 years earlier by using microirrigation. Young tree growth is improved because microsystems are more capable of controlling the water and nutrient status in the tree root zone. Microsystems can be operated frequently, and water and nutrients can be applied as needed on soils with low water and nutrient retention capacity. Water typically is applied only to the area in the immediate vicinity of the trees. Irrigated areas can be expanded as trees grow by adjusting the spray pattern and emitter position with respect to the tree. These practices allow the grower to maintain optimum soil moisture and nutrient status for rapid tree growth.

Conventional sprinkler and flood irrigation methods are not welladapted to the high-frequency applications required for growing young trees on sandy soils. Frequent sprinkler irrigation wastes water and energy, as watering large nonproductive areas between young trees is unavoidable. Frequent water applications are not possible with flood irrigation because of the time delays between pumping sufficient water to flood field ditches and draining them. Also, conventional systems cannot apply nutrients with the irrigation water efficiently.

\section{Yield increases}

Microirrigation increases yield compared with all irrigation systems, except permanent sprinklers (Koo, 1985; Zekri and Parsons, 1989). These increases are possible because permanent sprinkler and microirrigation systems frequently can be used to apply water to lowwater-holding capacity sandy soils. Microsystems also economically apply nutrients with irrigation water-an important factor considering the low fertility levels and low cation-exchange capacities of Florida's sandy soils.

Citrus yields increase as the soil surface covered by microirrigation increases (Koo, 1978; Koo and Smajstrla, 1984; Smajstrla and Koo, 1984). In humid regions where root systems are extensive due to frequent rainfall, irrigating a large fraction of the tree root zone is important. These results may explain why microirrigated citrus yields have not exceeded those of sprinkler-irrigated citrus under Florida production conditions

\section{Chemigation}

Frequent low-cost chemical applications in citrus orchards are possible using microirrigation systems. Although some growers apply pesticides and herbicides through microsystems, fertilizers are most commonly applied in this manner.

Frequent nutrient applications through microirrigation benefits production. This type of application increases yield compared with conventional fertilizer practices. Thus, for microirrigation to be most effective, water and nutrients should be applied simultaneously.

Some growers successfully apply complete fertilizers, including micronutrients, by chemigation. However, emitter clogging can be a problem when complete fertilizers or insoluble materials are injected into microirrigation systems. Injecting only water-soluble forms of $\mathrm{N}$ and $\mathrm{K}$ and applying other required nutrients once or twice per year by conventional methods minimizes clogging problems.

Clogging problems are combated by flushing nutrients from the system after injection, filtering, avoiding nutrient forms that precipitate in irrigation systems, and chemically treating water to reduce the potential for chemical or biological clogging. Although chemigation increases labor and management costs above those required for irrigation only, it is commonly practiced because these costs are offset by increased tree growth and yields, and reduced application costs.

Florida citrus growers typically apply fertilizers weekly or monthly. The low water-holding and nutrient retention capacities of Florida's sandy soils make these frequent applications necessary. Application costs for these high frequencies are less with micorirrigation than with conventional fertilizer application methods. Savings are greatest for young trees, because, with microirrigation, chemicals can be concentrated in the tree root zone rather than broadcast over nonproductive areas between trees.

\section{IRRIGATION SYSTEM COSTS}

\section{Initial costs}

The initial costs for an irrigation system strongly influence its acceptance and use. Costs vary widely, depending on site-specific characteristics and design criteria. For example, an irrigation well may cost at least $\$ 10,000$ or more than $\$ 50,000$ because of varying depths (range 60-300 m) and diameters (range 20-40 cm) used within the Florida citrus belt.

Well diameters and pump, power unit, and pipe sizes vary greatly, depending on whether the system is designed for freeze protection. For example, if a microsystem is designed for simultaneous irrigation of the entire grove for freeze protection, rather than for six zones, the system must have six times the capacity of the zoned system.

Pitts and Smajstrla (1989) estimated typical irrigation system costs 
for southern Florida, the site of much new grove development. Initial system costs per hectare ranged from $\$ 75$ to $\$ 250$ for seepage and flood irrigation, $\$ 3000$ to $\$ 5000$ for permanent solid-set sprinkler systems, $\$ 750$ to $\$ 1250$ for center pivot and traveling gun sprinkler systems, and $\$ 1500$ to $\$ 3000$ for microirrigation systems. These costs did not include land-forming costs, because land forming is required for drainage on flatwoods soils, regardless of irrigation system type.

\section{Pumping costs}

Microirrigation systems operate at lower pressures than conventional sprinkler systems. Microsystems also normally apply less water, especially for young trees, while groves are being established, thus, pumping costs commonly are less than those of sprinkler systems. Because of these lower volume and pressure requirements, pump, power unit, and main pipeline sizes and costs may also be reduced.

The reduction in microirrigation pumping costs are system-specific. If microsystems are designed for freeze protection, flow rate requirements are large because the entire grove must be irrigated simultaneously; thus, component sizes and costs may be large. However, pumping costs would still decrease if the operating pressure and total water volume applied were less than those of sprinkler irrigation.

Microsystems apply much less water than seepage and flood systems. However, because operating pressures are greater, pumping cost savings are site-specific. When well water is used for microirrigation, water savings can be much greater than the increase in total pumping head, thus, large pumping cost savings are possible. With a surface water supply, relative pumping head increases are greater with microirrigation, and pumping cost savings will be less.

\section{WATER CONSERVATION}

Compared with conventional irrigation, microirrigation conserves water. For Florida, the average water application efficiency (Ea) of well-designed, well-managed microsprinkler and drip irrigation systems is $\approx 80 \%$ and $\approx 85 \%$, respectively (Smajstrla et al., 1991). The difference in Ea relative to system type is due to greater wind drift and evaporation losses from microsprinklers. Irrigating at night or during early morning or late evening when wind drift and evaporation losses are low reduces these differences.

Ea values near $100 \%$ are not obtainable because flow and manufacturing variations in system components prevent perfectly uniform water application, and irrigation scheduling decisions are less than perfect. Flow variations in newly installed systems occur due to both pressure and manufacturing variations in system components, and later due to component wear and emitter clogging.

Pressure variations occur due to changes in elevation and friction losses in pipelines. Pressure variations cannot be avoided, and the cost to maintain extremely low variations is prohibitive. Thus, standards for well-designed, properly installed irrigation systems permit some pressure and flow variations.

The average water Ea of sprinkler systems is $\approx 70 \%$ for Florida conditions (Smajstrla et al., 1991). These lower Ea values primarily result from increased evaporation and wind drift losses that occur when water is sprayed at higher pressures over greater distances and normally higher elevations than with microsystems. Sprinkler irrigation efficiencies may be as high as microsystem efficiencies when mature groves are irrigated at night or at other times when wind drift and evaporation losses are low.

Seepage and flood system Ea values range widely because of varying water table and restrictive soil layer depths, soil hydraulic properties that permit downward or lateral water flows from the irrigated zone, and runoff or drainage water reuse. Much of the water applied to raise the water table is not available for crop use. An average $50 \% \mathrm{Ea}$ is sometimes used for comparing irrigation systems, although this value can vary widely for individual sites.

Compared with sprinkler and seepage systems, microsystems conserve water by restricting applications to areas beneath tree canopies. This method avoids nonproductive water losses due to evaporation from alleyway soil and transpiration from alleyway weeds and grass. Both sprinkler and seepage systems irrigate the entire land area, thus contributing to these nonproductive water uses. Microsystem efficiencies can be higher for young trees because nonproductive applications outside of the tree root zone can be minimized.

\section{GOVERNMENTAL REGULATIONS}

Governmental regulations have encouraged microirrigation use in the Florida citrus industry. In 1972, the Florida Legislature adopted the Florida Water Resources Act, which modified common-law water use doctrines and created five water management districts with broad statutory powers (Carriker and Lynne, 1978).

In 1975, the Florida Legislature passed the Florida Environmental Reorganization Act primarily to centralize authority for the numerous environmental programs previously administered by various state agencies (Wershow, 1976). This Act created the Dept. of Environmental Regulation (DER) as the central permitting agency to implement Florida's environmental programs, including water resource management. The DER approves permits for public water supply systems, waste disposal, dock and seawall construction, and dredge and fill operations. The water management districts issue permits for consumptive water use, well regulation, surface water management and storage, artificial recharge, and pond construction. Thus, the local district most directly influences irrigation water use in Florida, although the DER becomes involved if irrigation activities degrade surface or groundwater quality.

Florida's citrus belt is located in three of the five districts: the South Florida Water Management District, the Southwest Florida Water Management District (SWFWMD), and the St. Johns River Water Management District. Permitting regulations that affect citrus irrigation vary among management districts.

The Florida Water Resources Act requires that potential water users obtain water-use permits. They must demonstrate that the proposed water use is reasonable, beneficial, and consistent with the public interest, and will not interfere with existing legal water use or harm water resources (Wadley, 1976). Other specific provisions also may apply, depending on the district. In the SWFWMD, for example, the permit applicant must provide reasonable assurances that the water use 1) is necessary in the amount requested; 2) will not adversely affect water resources, wetlands or other natural resources, or an existing legal withdrawal; 3) will not cause water levels or flow rates to deviate from allowable ranges; 4) will use the lowest water quality appropriate; 5) will not induce saltwater intrusion; 6) will not pollute the aquifer; 7) will not impact off-site land use; 8) will use local water to the greatest extent possible; 9) will incorporate water conservation and reuse measures if practical; 10) will not waste water; and 11) will not otherwise harm district water resources (SWFWMD, 1989).

Items 9 and 10 encourage microirrigating citrus since the district considers it to be a highly efficient method. By discouraging runoff, these regulations also encourage using microsystems over gravity flow systems. Likewise, using smaller water quantities with microirrigation helps to avoid saltwater intrusion or conflicts with offsite users. However, these regulations do not prohibit using other irrigation methods if sufficient water is available and if no other negative effects occur.

The water management districts can declare water shortages and subsequently alter, modify, or declare invalid all or parts of a permit as necessary to address the shortage. SWFWMD encourages using microsystems through their water shortage plan. That plan defines water shortages in phases and mandates increasing cutbacks in water use as a shortage worsens, but it exempts microsystems from cutbacks during early water shortage phases. The plan also prohibits irrigation during certain daytime hours, but exempts microsystems and thus encourages microsystem use.

The districts can establish special regulations for water-use caution areas-areas that exhibit water resource problems due to competing uses or other reasons. Two such areas recently have been designated in the SWFWMD, and new applicants in these areas must meet high water-use efficiency criteria to obtain water-use permits. These regulations further encourage microirrigation use.

Water-use permit applicants also must document conservation measures that will be implemented and estimate the expected water 
savings from these measures. This information is used to determine the appropriate permitted water quantity. Again, this encourages, but does not mandate, microsystem use.

\section{LIMITATIONS}

As with almost all new technologies, there are limitations or disadvantages to using microirrigation systems. Two primary disadvantages for Florida citrus growers are emitter clogging and increased management intensity. Filtration, system flushing, andchemical water treatment are almost always required for effective microirrigation. These practices, as well as selecting appropriate emitters for specific water quality conditions, are critical for successful microirrigation.

The characteristic frequent small irrigations, filtration systems, and water treatment must be managed intensively for effective microirrigation. These requirements usually increase labor and demand a higher quality of labor than is required for conventional irrigation systems. Both of these factors lead to higher labor costs.

Florida citrus producers generally believe that the benefits of microirrigation systems outweigh their limitations, as evidenced by the rapid increase in microirrigated areas and new groves irrigated with microsystems. Most growers currently have some grove area in microsystems. They address the increased labor requirements by gradually increasing their microirrigated areas, which allows time to gain experience with this new technology and train workers to use it.

\section{SUMMARY}

The popularity of microirrigation for Florida citrus production is primarily due to this technology's many production benefits. Governmental regulations encourage microsystem use by limiting the water volume allocated to growers through water-use permits. The most severe restrictions primarily have occurred in water-use caution areas, during times of drought and water shortage, and along seacoasts where the potential for water quality degradation exists due to saltwater intrusion. However, many citrus growers currently hold permits for sprinkler and seepage irrigation systems.

Severe freezes that have damaged much of the northern citrus belt have encouraged using microirrigation in Florida citrus production. These freezes also have caused the Florida citrus industry to develop areas farther south, where the relatively high cost of sprinkler irrigation and the limited water available for seepage or flood irrigation have led to widespread microirrigation use.

Newly developed citrus groves are almost always irrigated by microirrigation. Microsprinkler systems are favored due to their economic benefits. Lower initial system and pumping costs, rapid young tree growth, and freeze protection are obtainable with this technology, and water conservation is a fringe benefit.

Florida's unique combination of soil, climate, and geological factors have led to wide microirrigation use in the Florida citrus industry. Sandy soils prohibit using surface irrigation, except for flood systems. Alternatives are limited to high-initial-cost sprinkler systems or high-water-requiring seepage or flood systems. Typical sandy soils have low water-holding capacities and low native fertility levels; thus, trees respond well to frequent irrigation and fertigation. Recent freezes have also led to increased use of microsprinkler systems for freeze protection. Geologically, Florida is subject to saltwater intrusion along coastal areas and in the southern peninsula. These water quality problems, as well as recent droughts, have caused water management districts to limit the water-use permits of growers who use less efficient irrigation methods. This unique combination of factors has encouraged the widespread adoption of microirrigation for Florida citrus production.

\section{Literature Cited}

Buchanan, D.W., F.S. Davies, and D.S. Harrison. 1982. High and low volume undertree irrigation for citrus cold protection. Proc. Fla. State Hort. Soc. 95:23-26.

Bush, R. 1990a. Florida citrus report: Gulf citrus continues expansion. FloridAgriculture 49(1):1, 11, 16.

Bush, R. 1990b. Decade of the freeze: Farmers hit by final blast. FloridAgriculture $49(2): 1,15-17$.
Bush, R. 1990c. Florida citrus makes amazing rebound. FloridAgriculture 49(10): 1,20

Carriker, R.R. and G.D. Lynne. 1978. The Florida Water Resources Act of 1972: A synopsis. Water Resources Council Fact Sheet WRC-9. Univ. of Florida, Inst. of Food and Agricultural Sciences, Gainesville.

Davies, F.S., L.K. Jackson, and L.W. Rippetoe. 1984. Low volume irrigation and tree wraps for cold protection of young Hamlin orange trees. Proc. Fla. State Hort. Soc. 97:25-27.

Ford, H.W. 1977. The importance of water quality in drip/trickle irrigation systems. Proc. Intl. Soc. Citriculture 1:84-87.

Ford, H.W. 1979. A key for determining the use of sodium hypochlorite to inhibit iron and slime clogging of low pressure irrigation systems in Florida. Fruit Crops Dept. Rpt. 79-6. Citrus Research and Education Center, Univ. of Florida, Lake Alfred.

Freie, R.L. and H.V. Young, Jr. 1989. Florida agricultural statistics: Citrus summary 1988-89. Florida Agricultural Statistics Service, Orlando.

Hardy, N.G. 1989. The story of Florida citrus. Florida Dept. of Citrus, Lakeland.

Jackson, J.L., Jr., D.H. Ayers, and L.R. Parsons. 1986. Performance of individual tree covers for cold protection of young trees. Proc. Fla. State Hort. Soc. 99:18-23.

Koo, R.C.J. 1978. Response of densely planted 'Hamlin' orange on two rootstocks to low volume irrigation. Proc. Fla. State Hort. Soc. 91:8-10.

Koo, R.C.J. 1985. Response of 'Marsh' grapefruit trees to drip, under tree spray and sprinkler irrigation. Proc. Fla. State Hort. Soc. 98:29-32.

Koo, R.C.J. and A.G. Smajstrla. 1984. Effects of trickle irrigation and fertigation on fruit production and juice qualityof 'Valencia' orange. Proc. Fla. State Hort. Soc. 97:8-10.

Koo, R.C.J., T. W. Young, R.L. Reese, and J.W. Kesterson. 1973. Responses of 'Beams' lemon to nitrogen, potassium and irrigation applications. Proc. Fla. State Hort. Soc. 86:9-12.

Oswalt, T.W. and L.R. Parsons. 1981. Observations on microsprinkler use for cold protection during 1981 freeze. Proc. Fla. State Hort. Soc. 94:52-54.

Parsons, L.R., B.S. Combs, and D.P.H. Tucker. 1985. Citrus freeze protection with microsprinkler irrigation during an advective freeze. HortScience 20:1078-1080.

Parsons, L.R., C. Taylor, B. Summerhill, and G. Israel. 1989. Cold protection survey: Major changes in a decade. Citrus Industry 70(11):46-48.

Parsons, L.R. and T.A. Wheaton. 1987. Microsprinkler irrigation for freeze protection: Evaporative cooling and extent of protection in an advective freeze. J. Amer. Soc. Hort. Sci. 112:897-902.

Parsons, L.R., T.A. Wheaton, and D.P.H. Tucker. 1986. Floridafreezes and the role of water in citrus cold protection. HortScience 21: 1, 176

Parsons, L.R., T.A. Wheaton, D.P.H. Tucker, and J.D. Whitney. 1982. Low volume microsprinkler irrigation for citrus cold protection. Proc. Fla. State Hort. Soc. 95:20-23.

Parsons, L.R., T.A. Wheaton, and J.D. Whitney. 1981. Low volume microsprinkler undertree irrigation for frost protection of young citrus trees. Proc. Fla. State Hort. Soc. 94:55-59.

Pitts, D.J., D.Z. Haman, and A.G. Smajstrla. 1990. Causes and prevention of emitter plugging in microirrigation systems. Florida Coop. Ext. Serv. Bul. 258. Univ. of Florida, Inst. of Food and Agricultural Sciences, Gainesville.

Pitts, D.J. and A.G. Smajstrla. 1989. Irrigation systems for crop production in Florida: Descriptions and costs. Florida Coop. Ext. Serv. Circ. 821. Univ. of Florida, Inst. of Food and Agricultural Sciences, Gainesville.

Reese, R.L. and R.C.J. Koo. 1976. Influence of fertility and irrigation on yield and leaf and soil analyses of 'Temple' orange. Proc. Fla. State Hort. Soc. 89:46-48.

Smajstrla, A.G., B.J. Boman, G.A. Clark, D.Z. Haman, D.S. Harrison, F.T. Izuno, D.J. Pitts, and F.S. Zazueta. 1991. Efficiencies of Florida agricultural irrigation systems. Florida Coop. Ext. Serv. Bul. 247. Univ. of Florida, Inst. of Food and Agricultural Sciences, Gainesville.

Smajstrla, A.G. and R.C.J. Koo. 1984. Effects of trickle irrigation methods and amounts of water applied on citrus yields. Proc. Fla. State Hort. Soc. 97:37.

Southwest Florida Water Management District. 1989. Water use permit information manual. Southwest Florida Water Management District, Brooksville.

Trulio, M. (ed.). 1960-89. Annual irrigation survey. Irrigation J. Adams Publishing Co., Encino, Calif.

Wadley, J.B. 1976. Summary guide to Florida's water rights. Florida Coop. Ext. Serv. Circ. 412. Univ. of Florida, Inst. of Food and Agricultural Sciences, Gainesville.

Wershow, J.S. 1976. Legal implications of water management for Florida's future. Water Resources Council Fact Sheet WRC-6. Univ. of Florida, Inst. of Food and Agricultural Sciences, Gainesville.

Zekri, M. and L.R. Parsons. 1989. Grapefruit leaf and fruit growth in response to drip, microsprinkler and overhead sprinkler irrigation. J. Amer. Soc. Hort. Sci. 114:25-29. 